\title{
Towards an E-Learning Support Strategy for the Retail Sector in South Africa
}

\author{
Jonathan M. Aspeling, Cape Peninsula University of Technology, South Africa \\ Roger B. Mason, Cape Peninsula University of Technology, South Africa
}

\begin{abstract}
E-learning is of increasing importance in delivering flexible and distributed programmes for workforce skill development such as induction, product knowledge, systems compliance, and customer service. This research consists of a desktop exploratory review of e-learning concepts, policies, surveys, and a set of proposals and recommendations from research into e-learning in the retail sector. The article presents international and local experience, relevant post-school education and training policies and key variables and themes that impact on e-learning. Institutional approaches in supporting e-learning within different countries are also contrasted. The outcomes are general recommendations regarding the focus, alignment and integration of e-learning for the retail sector, with activities proposed to support e-learning.
\end{abstract}

\section{KEYWORDS}

Developing Country, Education, E-Learning, Retail, Technology, Workplace Learning

\section{INTRODUCTION}

The wholesale and retail industry are the fourth largest contributor to South Africa's Gross Domestic Product while employing approximately $21 \%$ of the total workforce (W\&RSETA, 2014). All companies in South Africa contribute via a levy to fund sector education and training authorities (SETAs) which facilitate training in their specific industries. The Wholesale and Retail Sector Education and Training Authority (W\&RSETA) facilitates skills development through the implementation of learning programmes, disbursement of grants and monitoring of education and training (W\&RSETA, 2016). One of the W\&RSETA strategic objectives is the development of a comprehensive e-learning system to support the wholesale and retail sector. Research conducted for the W\&RSETA set out to obtain e-learning perspectives and information from the retail industry regarding access and attitudes of companies to e-learning and also to evaluate companies' readiness for e-learning. Findings from the surveys showed that a comprehensive and systematic approach to formulation of an e-learning strategy for the wholesale and retail industry is needed (Training Room online, 2014).

A change is taking place in the provision of post school education, with a shift in approach with regard to post school education and training. With some exceptions such as Australia, most policies focus on formal academic tertiary institutions as opposed to vocational training and non-formal

This article, originally published under IGI Global's copyright on July 1, 2020 will proceed with publication as an Open Access article starting on January 28, 2021 in the gold Open Access journal, International Journal of Web-Based Learning and Teaching Technologies (converted to gold Open Access January 1, 2021), and will be distributed under the terms of the Creative Commons Attribution License (http:// creativecommons.org/licenses/by/4.0/) which permits unrestricted use, distribution, and production in any medium, provided the author of the original work and original publication source are properly credited. 
e-learning experiences. A number of private training organisations and large corporations are using e-learning (Ettinger, Holton, \& Blass, 2005). This change is also happening in South Africa so an e-learning system and support for the wholesale and retail sector e-learning is needed. As a result, a strategy and an e-learning approach is required to enable the W\&RSETA to create an e-learning system to facilitate skills development within the wholesale and retail industry and to give guidance to the industry.

In the retail workplace learning refers to the ongoing process of improving employee competence and performance through training, socialization, and development within an organizational context. The benefits of e-learning from a workplace perspective can be grouped into three broad categories: in the first instance, e-learning improves access to training and allows training to be delivered flexibly in terms of time and place in order to meet the needs of the employer and employee; secondly, e-learning is seen as means of ensuring consistent and scalable training, while ensuring compliance with standards and best practice; and thirdly e-learning is seen as sustainable and cost effective and results in minimal stoppages and time-off-task. E-learning also helps improve and increase the basic skills of employees, providing the organisation with a competitive advantage (Clayton \& Elliott, 2008). These benefits are confirmed internationally and within a South Africa retail context where e-learning is stated to have decreased the costs of up-skilling a workforce by reducing travel and employee time away from work (Callahan, 2010; Shoprite, 2015) and is useful for a geographically dispersed workforce because it can deliver a consistent training experience (Becker, Fleming, \& Keijsers, 2012; Brown \& Charlier, 2013).

The objective of this research project was therefore to provide a background for the development and implementation of an e-learning strategy for the wholesale and retail industry in South Africa, a developing country that is leading the way in retailing on the African continent. Specific outcomes from the study are:

- A common understanding of the e-learning concept in a retail context;

- Specific activities for e-learning in the retail sector;

- Provide guidelines for the implementation of e-learning.

\section{METHODOLOGY}

The purpose of the study was exploration, using secondary data as sources of information. Most of this data was essentially qualitative and a review of extant literature was employed as the collection methodology (Sekaran \& Bougie, 2013). Such literature studies seek to establish which information exists as it pertains to a specific research topic and the related wider subject area. This methodology is used because of the high levels of uncertainty regarding the concept of e-learning within the South African wholesale and retail context and also because of the uncertainty as to how implementation of e-learning within a workplace context should be supported in the industry. Such exploratory research is warranted where the intention is to gain a better understanding of a topic where some facts are known but more details are needed to better understand the situation (Sekaran \& Bougie, 2013).Thus, this study consists of a review of e-learning concepts, policies and e-learning-related South African legislation. Workplace learning and the wholesale and retail sector were the focus of the secondary data collection in terms of the scope and objectives of the project.

\section{Data Collection, Sources and Selection of Literature}

Prior to project initiation, ethics approval was received from the CPUT Research Ethics committee, as per Ethical Clearance certificate number 2015 FBREC 330.

Data collection made use of two methods of literature search; first, searches for information originally collected as primary data in peer reviewed journal articles, dissertations and e-learning 
reports and use of the snowball technique to acquire further data, and second, searches for secondary sources of information, documents and reports that apply to e-learning specific to the South African situation. Data collection began in late 2016 and continued into 2018 with data collection and analysis being conducted as an iterative process as suggested by Henning, van Rensburg and Smit (2004).

The searches made use of online databases (EBSCOhost Business Source Premier, SpringerLink, ProQuest Education, Open Access Digital Library, Wiley online, Gale Cengage One File, Taylor and Francis Journals, Elsevier, and Emerald journal collection) using the following key terms as general search criteria:

- e-learning definitions

- e-learning frameworks

- e-learning and vocational education

- e-learning and workplace learning

- e-learning and retailing

- e-learning policy

- e-learning support organisations

- South African e-learning policies

- e-learning in Africa

Additional searches for sources of information, documents and reports that apply to e-learning in South Africa were undertaken within the following sources:

- A search of international retail and human resources trade journals was completed with specific reference to e-learning and retailing;

- The South African Government's official website to access relevant education and training white papers or reports;

- A search of websites of a list of organisations supporting e-learning internationally;

- Previous research commissioned by the W\&RSETA with large and small retailers to assess e-learning;

- Glossaries that refer to e-learning terminology.

Following the initial search of the literature for secondary data, a process of refining documents to be used in the review was undertaken. The objectives of the research project, mandate and workplace focus of the W\&RSETA guided the inclusion or exclusion of literature collected:

- The key objective of the research was to determine what approaches could be taken by the W\&RSETA to support e-learning within the South African wholesale and retail sector. This made documents such as cross-country e-learning policies and bibliometric analysis of e-learning research particularly relevant;

- The legislated mandate of the W\&RSETA is implementation, disbursement and monitoring of learning activities. Reports referring specifically to support for e-learning training and education and quality assurance in a retail context were sought;

- The focus of W\&RSETA activities is on higher and occupational education level. This, to a large extent, excluded pedagogic and secondary education applications, general e-learning systems and specific technologies. Documents referring to higher education and occupational or vocational education were viewed as relevant.

Inclusion: Documents that provided bibliometric analysis of e-learning research and annotated bibliographies of e-learning, cross country reports on e-learning and educational technology 
policy, higher education and vocational education articles and reports. Reports included were those specifically referring to e-learning within the international retail industry.

Exclusion: Documents addressing pedagogic aspects of e-learning, documents addressing e-learning for secondary education, organisation specific studies, e-learning benchmarking surveys, e-learning design documentation and tools, analysis of specific technologies such as learner management systems (LMS) or other technologies. Also excluded were international education and training policies and documents and general documentation and articles on quality assurance in e-learning.

Restrictions: In addition to exclusions, the following restrictions were placed on the selection of relevant data. Generally, secondary data in English about e-learning in South Africa and to technology was restricted to about the previous 5 years, although literature relevant to definitions and explanation of processes, policies and guidelines going back 10 years was considered where necessary.

\section{Analysis and Interpretation}

Since this was essentially a qualitative study, content analysis using a priori coding, was used to analyse the data (Maree, 2010). The deconstruction and reconstruction approach suggested by Lee (1999) was used to break each data source down according to the specific focus or theme codes, and then reconstructed into each theme or focus area. How this was conducted is explained below.

Literature sources included in the review were sorted into three themes, or focus areas aligned to the scope and outcomes of the project. The areas of focus were:

Area 1: E-learning concepts, definitions and frameworks, workplace literature and retail industry related e-learning experience.

Area 2: International e-learning policy experiences including South African legislation related to post schooling education and training where reference is made to e-learning.

Area 3: Methods of supporting e-learning in education and training programmes that are internationally employed and feedback from the South African retail industry.

A focus area centred approach was used to review and analyse the literature collected. This involved the creation of a table or matrix for each area identified. Studies, reports and legislation artefacts were grouped into the three areas in order to organise, review and critically analyse the literature. Points of departure (POD) were identified for each of the focus areas. Information was recorded through a review and analysis of the full text of articles and/or reports that formed part of a specific group:

- $\quad$ Bibliometric analysis of literature and annotated bibliographies were utilised as POD in area 1 to identify and confirm key themes and findings. Source literature was consulted during analysis when identified to be relevant;

- International reports referring to e-learning policy and South African specific legislation related to education and training were utilised as POD in area 2. Full texts of reports and legislation were reviewed, analysed and summarized;

- International expert input into lists of organisations supporting e-learning were utilised as POD for area 3 in addition to two research reports commissioned by the W\&RSETA in 2014. Verification of the list of support organisations and roles was confirmed by a review of the websites or/and annual reports of relevant organisations. 


\section{Trustworthiness of the Study}

Ensuring trustworthiness focusses on determining whether the findings are credible or plausible. 'Method-appropriate criteria', namely data triangulation (use of multiple data sources), peer debriefing (involvement of co-author, other colleagues, and industry members in reviewing analysis results via a post hoc focus group) validated the procedures, increasing rigor and trustworthiness (Flick, 1998). These methods also ensured transferability. According to Babbie and Mouton (2001) the trustworthiness of a qualitative study is ensured through achieving credibility and transferability.

\section{A SYSTEMS FRAMEWORK OF E-LEARNING AND WORKPLACE LEARNING}

In order to gain a clearer perspective of the e-learning ecosystem and its linkage to the workplace, a systems based theoretical framework recently developed by Aparacio (2016) can be used to explain the components of e-learning and to highlight some of the different research streams in the field. This framework is complemented by an approach to understanding e-learning uses by Bates and Planning (2001) which indicates e-learning could be used for purposes of workplace learning. In terms of a systems approach to understanding the e-learning ecosystem, systems' thinking requires that e-learning be seen in its overall context which is made up of various internal systems, each of which potentially influences or is influenced by the others (Nichols \& Anderson, 2005; Aparicio et al., 2016). Figure 1 summarises the e-learning field and provides high level insights in terms of the

Figure 1. Holistic e-learning systems theoretical framework (Source: Aparicio et al., 2016, p. 302)

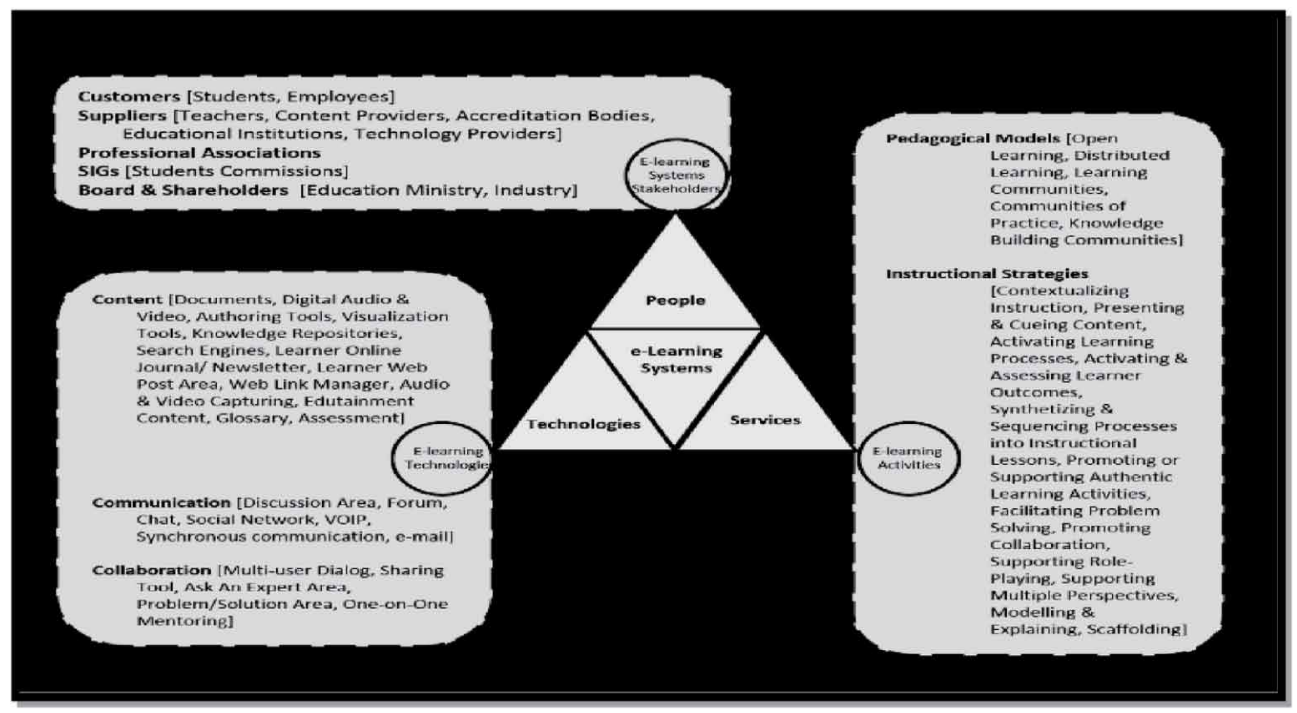

three dimensions asserted to be the main dimensions of e-learning, namely, people, technologies and services (Aparicio et al. 2016).

The framework identifies a number of e-learning systems stakeholders which may be internal or external stakeholders that impact on, or are impacted on by, e-learning. Successful implementation of e-learning is dependent on the extent to which the needs and concerns of the stakeholder groups involved are understood and addressed and the clarification of the responsibilities of stakeholders (Wagner et al., 2015). The formulation of a policy for e-learning directly involves stakeholder participation. The pedagogical models that underpin e-learning are extensively researched, discussed 
and debated in the texts, as are the instructional strategies, and the learning technologies. These three components enable the linkage between who (open learning, distributed learning, or communities of practice, among others) the learning process is targeted at, with the way in which these features interact (collaborating, articulation, reflecting, exploring) and the technologies through which the learning occurs (synchronous, asynchronous, communication tools or course management tools, among others).

A further approach to understanding e-learning that brings the discussion closer to workplace learning addresses the reasons for use of e-learning is put forward by Bates and Planning (2001), who identifies three main types of uses of e-learning: (a) technology-enhanced classroom teaching, (b) distance education and (c) distributed or flexible learning. The first refers to technological innovations in existing face-to-face settings. A second use is in distance education, which recognises the need to make provision for access to educational services for students studying at a distance or for those who cannot attend face-to-face courses for whatever reasons. A third use of e-learning that appears particularly relevant from a W\&RSETA and retail industry perspective is where e-learning is used for distributed or flexible learning. Distributed or flexible learning makes it possible to offer more flexible forms of delivery than traditional classroom teaching. The key point is that flexible learning does not serve the same purpose as distance education and this distinction has not been well articulated in most texts (Bates \& Planning, 2001). Distributed Learning is an instructional model that allows instructor, students, and content to be located in different, non-centralized locations so that instruction and learning can occur as asynchronous learning. E-learning can provide distributed or flexible learning options for employees and allow them to up-skill more rapidly (Anderson, 2011). Distributed or flexible forms of training delivery as offered by e-learning systems are particularly relevant in a workplace context and equally within a wholesale and retail industry context.

\section{WHOLESALE AND RETAIL WORKPLACE PERSPECTIVES ON E-LEARNING}

To understand the context within which the W\&RSETA will implement its e-learning approach within the wholesale and retail sectors, it is important to review e-learning from a workplace approach both in an international and South African wholesale and retail context.

In the workplace or retail industry, learning refers to the ongoing process of improving employee competence and performance through training, socialization, and development within an organizational context. The drivers, benefits and barriers to e-learning from a workplace perspective have been extensively researched and documented in literature and are summarised in Figure 2.

Of particular significance is that the factors driving and impacting on e-learning are particularly relevant to the South African wholesale and retail industry and should form part of the W\&RSETA approach to supporting the industry. These factors are equally true in international retailing and are identified during the course of e-learning readiness surveys conducted at large and small South African retailers.

E-learning experience is specifically reviewed in wholesale and retail by:

- Reviewing e-learning studies in the UK, USA and Canadian retail sector that detail types of training, barriers, drivers and technologies;

- Reviewing the current status of e-learning by major South African retailers and the e-learning readiness at large and small South African retailers;

- Identifying and contrasting support strategies that are internationally employed by a range of organisations to support e-learning providers and programmes.

\section{International Experience}

A number of benchmarking surveys from a human resources or training perspective have been completed involving retail organisations in the UK, USA and Canada, of which in excess of $60 \%$ 


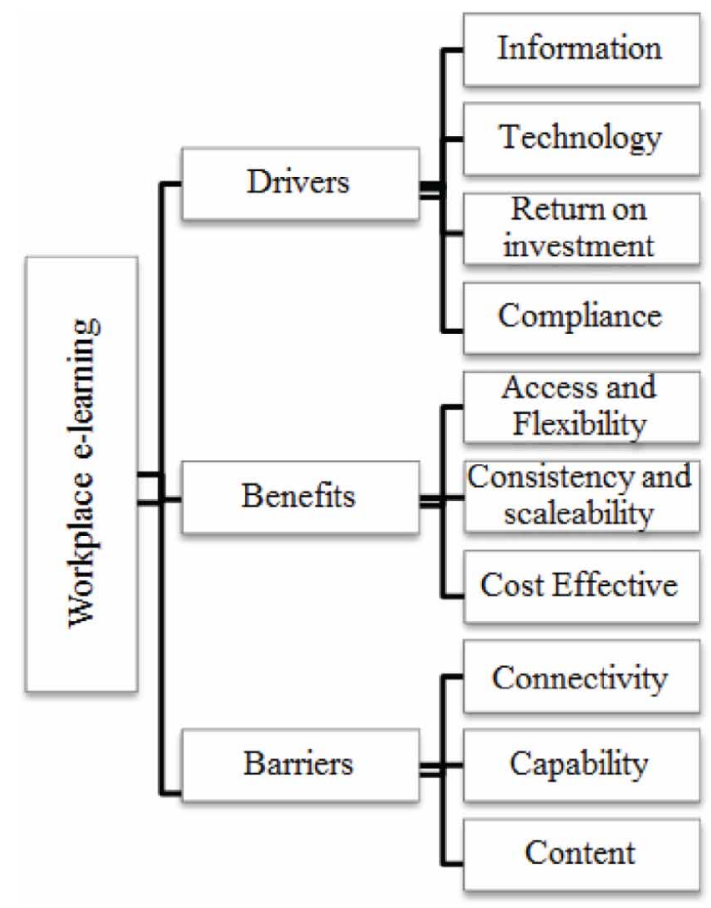

employed more than 5000 staff members. These surveys were completed between 2011 and 2015 and provide insights into the international retail e-learning experience. A number of key issues from a retail or business perspective were identified - these being the move towards blended learning, barriers and drivers, where e-learning is used, and technologies being used in retail. As shown in Table 1,

Table 1. Types of learning modality by retail sector

\begin{tabular}{|l|l|l|l|}
\hline & \multicolumn{1}{|c|}{ UK } & \multicolumn{1}{|c|}{ USA } & \multicolumn{1}{c|}{ Canada } \\
\hline Classroom or face-to-face learning & $14 \%$ & $37 \%$ & \\
\hline Blend of classroom and online learning & $84 \%$ & $25 \%$ & $76 \%$ \\
\hline Online only & $2 \%$ & $38 \%$ & \\
\hline
\end{tabular}

(Source: Adapted from: Retail Council of Canada (2015); Dixon and Overton (2015); Trainingmag (2014))

e-learning appears to be growing in use at retail workplaces internationally with an estimate $38 \%$ of training in UK retailers being online in 2015 (Dixon \& Overton, 2015) and up to 96\% of retailers in Canada making use of e-learning (Retail Council of Canada, 2015). The approach of using e-learning as a flexible and distributed approach to training is evident from the shift from classroom or face to face learning to blended learning, with the USA moving beyond blended learning to training that is purely on-line (Trainingmag, 2014). It appears that, internationally, the bulk of e-learning training at retailers now takes place on a blended approach which is consistent with the move to e-learning that is being reported by South African retailers (Shoprite, 2015). 
A recurrent theme in international retail e-learning surveys is that specific types of training are favoured in the e-learning environment. Compliance training such as health and safety and industry specific regulatory compliance appears to be a major source of e-learning and is the number one area of e-learning among Canadian retailers surveyed (Retail Council of Canada, 2015), with 72\% of USA companies doing this type of training online (Trainingmag, 2014), while 64\% of compliance training in UK retailers is done online (Dixon \& Overton, 2015). A comparison of training offered online in Table 2 indicates that a wide range of skills are offered online by retailers.

Table 2. Skills training offered via e-learning internationally in wholesale and retail

\begin{tabular}{|c|c|c|c|}
\hline Skills Being Offered via E-Learning & UK & USA & Canada \\
\hline Leadership and management skills & $\mathrm{x}$ & $\mathrm{x}$ & $\mathrm{x}$ \\
\hline Induction & $\mathrm{x}$ & $\mathrm{x}$ & $\mathrm{x}$ \\
\hline Health and safety & $\mathrm{x}$ & $\mathrm{x}$ & $\mathrm{x}$ \\
\hline General IT and web user skills & $\mathrm{x}$ & $\mathrm{x}$ & \\
\hline Team working / Working with others & $\mathrm{x}$ & & \\
\hline Communication / Interpersonal skills & $\mathrm{x}$ & $\mathrm{x}$ & \\
\hline Industry specific regulatory requirements & $\mathrm{x}$ & & $\mathrm{x}$ \\
\hline Customer handling/service & $\mathrm{x}$ & $\mathrm{x}$ & $\mathrm{x}$ \\
\hline Sales and marketing & $\mathrm{x}$ & $\mathrm{x}$ & \\
\hline Company specific skills (not provided & $\mathrm{x}$ & $\mathrm{x}$ & \\
\hline Foreign language skills & $\mathrm{x}$ & & \\
\hline Basic skills (literacy, numeracy, English) & $\mathrm{x}$ & & \\
\hline IT professional skills & $\mathrm{x}$ & $\mathrm{x}$ & \\
\hline Problem solving & $\mathrm{x}$ & & \\
\hline Improving own learning and performance & $\mathrm{x}$ & & \\
\hline (Research and development skills) & $\mathrm{x}$ & & \\
\hline Internal systems and processes & $\mathrm{x}$ & & $\mathrm{x}$ \\
\hline Project / service management & $\mathrm{x}$ & & $\mathrm{x}$ \\
\hline
\end{tabular}

(Source: Adapted from: Fiehl, Diaz, \& Solom (2011); Dixon and Overton (2015); Retail Council of Canada (2015); Trainingmag (2014))

Barriers and drivers of e-learning, from a structural or management perspective specific to retailing, are to a large extent consistent with barriers and drivers that are experienced internationally by businesses in general. They are highlighted in the literature as related to connectivity, content and capability. The barriers are detailed as reported in specific retail company e-learning surveys and matched with the specific factors that are the source of the barrier as per Clayton's analysis of structural barriers to e-learning (Clayton \& Elliott, 2008). Staff barriers also align with factors, established through research, that apply in general to most businesses where e-learning is implemented and are contrasted with the restraining factors that inhibit use of e-learning by staff within a retail context as identified by Rabak and Cleveland-Innes (2006). These barriers are summarised in Table 3.

The drivers of e-learning, identified within a retail context, emphasize the importance of provision of information to staff, induction of staff and sales focus (Pappas, 2015). The drivers identified specifically in retailing are contrasted with the general drivers in Table 4. 
Table 3. Barriers to e-learning in wholesale and retail compared to general barriers in e-learning

\begin{tabular}{|c|c|}
\hline Structural and Management Barriers as Identified in Retail E-Learning Surveys & Driver/Barrier \\
\hline Unreliable infrastructure/low bandwidth/technical factors & Connectivity \\
\hline Cost of set-up, development and maintenance & Connectivity \\
\hline Lack of skills amongst employees to manage own learning & Capability \\
\hline Lack of skills amongst L\&D staff to implement and manage e-learning & Capability \\
\hline Insufficient staff access to computers to be worthwhile & Connectivity \\
\hline Lack of support from IT department & Capability \\
\hline Not seen as a management priority & Capability \\
\hline Past experience of e-learning hasn't fulfilled our expectations & Capability \\
\hline Lack of attractive high-quality e-learning that supports our business goals & Content \\
\hline Staff Related Barriers as Identified in Retail E-Learning Surveys & Limiting Factors \\
\hline Existing control and command culture/Policy-related & $\begin{array}{l}\text { Concern about employer } \\
\text { monitoring }\end{array}$ \\
\hline Technology or IT security related & Fear of technology \\
\hline Issues of user safety, identify or trust & $\begin{array}{l}\text { Unsuccessful in previous } \\
\text { training }\end{array}$ \\
\hline \multicolumn{2}{|l|}{ Social media is the domain of other departments } \\
\hline "Head in the sand" mentality - it will go away & Resistant to change \\
\hline L\&D staff won't facilitate social learning & $\begin{array}{l}\text { Concern about employer } \\
\text { monitoring }\end{array}$ \\
\hline Our learners are unwilling to share with each other & Low self-confidence \\
\hline
\end{tabular}

(Source: Adapted from: Clayton and Elliott (2008); Rabak and Cleveland-Innes (2006))

The prevalence of learning management systems as technologies to deliver content and to assist in management of e-learning is shown in Table 5. Important within the context of e-learning at retailers is to take cognisance of the fact that online assessment in a workplace context is not currently extensively utilised internationally other than in the UK retailers.

\section{South African Wholesale and Retail Industry}

Factors that constrain skills development programmes within the South African wholesale and retail (W\&R) sector are: the size and diversity of the sector; the large numbers of employees; geographical disparities; costs and a lack of standardisation and accessibility of training activities. In attempting to overcome these constraints, retailers are increasingly using information communication technologies (ICTs) to reduce training costs and improve effectiveness (Shoprite, 2015). Technology enhanced learning (TEL) (Australian Flexible Learning Framework, 2011) appears to be growing in popularity and use in this sector. Evidence of the increased use of technology for offering training in the retail industry is demonstrated in the following extracts from six national retailer's annual reports and websites:

1. "Our new e-learning methodology assists us in the rapid roll out of induction; product knowledge; compliance; and customer service related training. The implementation of e-learning in our Supermarket store environment leads to a substantial increase in training interventions (45\%) and beneficiaries (27\%). It enables us to take learning to people as opposed 
Table 4. Drivers of e-learning in international retailing

\begin{tabular}{|c|c|}
\hline Drivers of E-Learning in a Retail Context & E-Learning Drivers \\
\hline Improve induction process & Information \\
\hline Increase learning access and flexibility & Information \\
\hline Increase ability to adapt programme to business requirements & Return on investment \\
\hline Develop a better qualified workforce & Return on investment \\
\hline Comply with new regulations and legal requirements & Compliance \\
\hline Help implement new processes or new products & Compliance \\
\hline Increase on the job productivity & Return on investment \\
\hline Improve customer satisfaction & Return on investment \\
\hline Improve staff retention & Return on investment \\
\hline Help implement new IT systems & Compliance \\
\hline Support organisational change & Compliance \\
\hline Inform customers/suppliers of new products/services & Return on investment \\
\hline Engage new types of learners & Information \\
\hline Provide a faster response to changing & Information \\
\hline Speed up and improve the application of learning & Technology \\
\hline Reduce time to competence & Technology \\
\hline Increase the ongoing sharing of good practice & Information \\
\hline Push updated information to employees & Information \\
\hline Improve talent/performance management & Return on investment \\
\hline Improve employee engagement with learning & Technology \\
\hline Improve effectiveness of face-to-face learning & Return on investment \\
\hline Improve staff motivation & Return on investment \\
\hline Extend learning to remote workers & Technology \\
\hline
\end{tabular}

(Source: Adapted from: Fiehl et al. (2011); Retail Council of Canada (2015); Trainingmag (2014); Dixon and Overton (2015))

Table 5. E-learning technologies used internationally by wholesalers and retailers

\begin{tabular}{|l|l|l|l|}
\hline \multicolumn{1}{|c|}{ Technologies Being Used for E-Learning } & \multicolumn{1}{c|}{ UK } & \multicolumn{1}{c|}{ CSA } & $\mathrm{x}$ \\
\hline Learning management systems & $\mathrm{x}$ & $\mathrm{x}$ & \\
\hline Surveys and questionnaires & $\mathrm{x}$ & & \\
\hline Online assessment & $\mathrm{x}$ & $\mathrm{x}$ & \\
\hline Custom-made e-learning objects & $\mathrm{x}$ & $\mathrm{x}$ & \\
\hline Virtual meetings & $\mathrm{x}$ & & \\
\hline Best practice (internal) videos & $\mathrm{x}$ & & \\
\hline External social networking sites & $\mathrm{x}$ & $\mathrm{x}$ & $\mathrm{x}$ \\
\hline Rapid application development tools & $\mathrm{x}$ & & \\
\hline Open education resources & & & \\
\hline
\end{tabular}

(Source: Adapted from: Fiehl et al. (2011); Retail Council of Canada (2015); Trainingmag (2014); Dixon and Overton (2015)) 
to driving people to learning facilities and therefore creates massive savings through reduced travel and accommodation costs, less time out of production, and less facilitation and learner administration time. It facilitates a paperless environment that saves tremendous printing, courier and environmental costs" (Shoprite, 2015);

2. "In the past year, provided retailers with tablet devices that contain the "Fresh Studio" - a full, online manual that provides information about every department, its products and systems. It includes all relevant legislation, recipes, food labelling, merchandising, display, as well as costing recommendations" (Spar, 2014);

3. "Over 330 training programmes offered to employees, ranging from basic literacy and numeracy through to computer-based training and management and leadership programmes" (Pick 'n Pay, 2014);

4. "R5.1 million spent on e-learning in the current year (R29.7 million spent to date). This technology makes training available to associates on a daily basis regardless of where they are geographically located" (MrPrice, 2015);

5. "Implementation of an enterprise knowledge and collaboration solution for group employees" (TFG, 2014);

6. "Our virtual university has access to renowned content experts and faculty from local and overseas institutions. All our materials are designed by content experts and company subject matter experts" (Massmart, 2013).

Therefore, given the rapid growth of technology based initiatives in this sector, the readiness of the local industry and the absence of national or industry guidelines on e-learning policies, the industry, as a matter of urgency, requires that a strategy and a policy for e-learning be developed in order to guide the implementation of e-learning in training for the achievement of the industry's strategies. Two surveys commissioned by the W\&RSETA, one of small retailers and the other of large retailers, found that a comprehensive and systematic approach to formulation of an e-leaning strategy and policy that addresses sector demand and supply side considerations is needed (Training Room online, 2014). This is supported in international literature in a study which evaluated successful e-learning strategies (Anderson, Brown, Murray, Simpson, \& Mentis, 2006; Department of Industry, Innovation, Science, 2012). In the South Africa context, no specific national e-learning policy exists, other than that within the context of distance education (Council on Higher Education, 2012), against which to benchmark and comply with in designing e-learning practices. Table 6 summarises some of the pertinent findings that indicate readiness of the large and small retailers for e-learning.

Key recommendations were made from the two W\&RSETA surveys, based on the inputs of a broad spectrum of employees from the retailers, regarding the role that the W\&RSETA could play with respect to e-learning. These included: providing an e-learning platform (host a platform, create a platform for qualifications and maintain a platform); capacity building (which includes training of key employees and providing technical support); developing and providing resources (developing a budget and proving learning resources); and implementing policy and strategy (having a policy and strategy and developing a business case) - see Figure 3.

The above results give insight into e-learning readiness of large and small retailers and recommendations on the role that the W\&RSETA could play with respect to e-learning. These insights could be used by all large and small retailers in South Africa who are implementing, or planning to implement, e-learning in their training practices.

\section{Sector Training Authorities}

A review of the websites of the majority of SETAs did not indicate that any specific policies for e-learning are in place. INSETA has produced a guideline document for e-learning accreditation with a checklist that is linked to the SAQA quality criteria (Insurance SETA, 2014). The guideline document identifies accreditation, monitoring and verification requirements and makes use of Massey 
Table 6. E-learning readiness of South African large and small retailers

\begin{tabular}{|c|c|c|}
\hline Aspect & Large Retailers & Small Retailers \\
\hline $\begin{array}{l}\text { Support for } \\
\text { e-learning at } \\
\text { management } \\
\text { level }\end{array}$ & $\begin{array}{l}\text { Company management is generally } \\
\text { supportive of e-learning for employees } \\
(65.9 \%) \text {. They realise the value }(73.2 \%) \text { and } \\
\text { benefits of e-learning }(75.7 \%) \text {. }\end{array}$ & $\begin{array}{l}\text { Company management is generally supportive of } \\
\text { e-learning for employees }(77.6 \%) \text {. They realise the } \\
\text { value }(84.1 \%) \text { and benefits of e-learning }(81.3 \%) \text {. }\end{array}$ \\
\hline $\begin{array}{l}\text { Use of } \\
\text { e-learning }\end{array}$ & $\begin{array}{l}\text { Currently the companies are not using } \\
\text { e-learning as part of its total training plan } \\
(65.9 \%) \text { and investing in e-learning for } \\
\text { employees ( } 63.4 \%) \text {. This means that } 34 \% \text { of } \\
\text { companies are using e- using e-learning. }\end{array}$ & $\begin{array}{l}\text { Currently the companies are not using e-learning as } \\
\text { part of its total training plan }(67.3 \%) \text { and investing } \\
\text { in eLearning for employees }(61 \%) \text {. This means that } \\
33 \% \text { of companies are using e-learning }\end{array}$ \\
\hline $\begin{array}{l}\text { Infrastructure } \\
\text { and staff ability }\end{array}$ & $\begin{array}{l}\text { About } 41.4 \% \text { of companies have an } \\
\text { IT infrastructure that can support the } \\
\text { implementation of eLearning and } 43.9 \% \\
\text { of employees have basic skills to operate a } \\
\text { computer }\end{array}$ & $\begin{array}{l}\text { A large proportion of small businesses do not have } \\
\text { computers which make e-learning a challenge. About } \\
6.1 \% \text { of employees have basic skills to operate a } \\
\text { computer; } 54 \% \text { can use the internet and } 46 \% \text { have } \\
\text { technical support for e-learning }\end{array}$ \\
\hline Support required & $\begin{array}{l}\text { The companies require support in training; } \\
\text { guidelines, strategy and plan for the } \\
\text { implementation of e-learning; facilitator } \\
\text { development; resourcing; training needs } \\
\text { analysis; technical support; connectivity }\end{array}$ & $\begin{array}{l}\text { Companies require support in training; guidelines, } \\
\text { strategy and plan for the implementation of } \\
\text { e-learning; facilitator development; resourcing; } \\
\text { training needs analysis; technical support; and } \\
\text { connectivity }\end{array}$ \\
\hline $\begin{array}{l}\text { Retailers view } \\
\text { on e-learning }\end{array}$ & $\begin{array}{l}\text { Respondents were incredibly optimistic } \\
\text { about the value and benefits of e- learning }\end{array}$ & $\begin{array}{l}\text { Respondents showed a very positive attitude to } \\
\text { the concept of e-learning with employees showing } \\
\text { willingness a willingness to support }\end{array}$ \\
\hline
\end{tabular}

(Source: Adapted from: Training Room online (2014))

Figure 3. Key recommendations on role that W\&RSETA could play with respect to e-learning
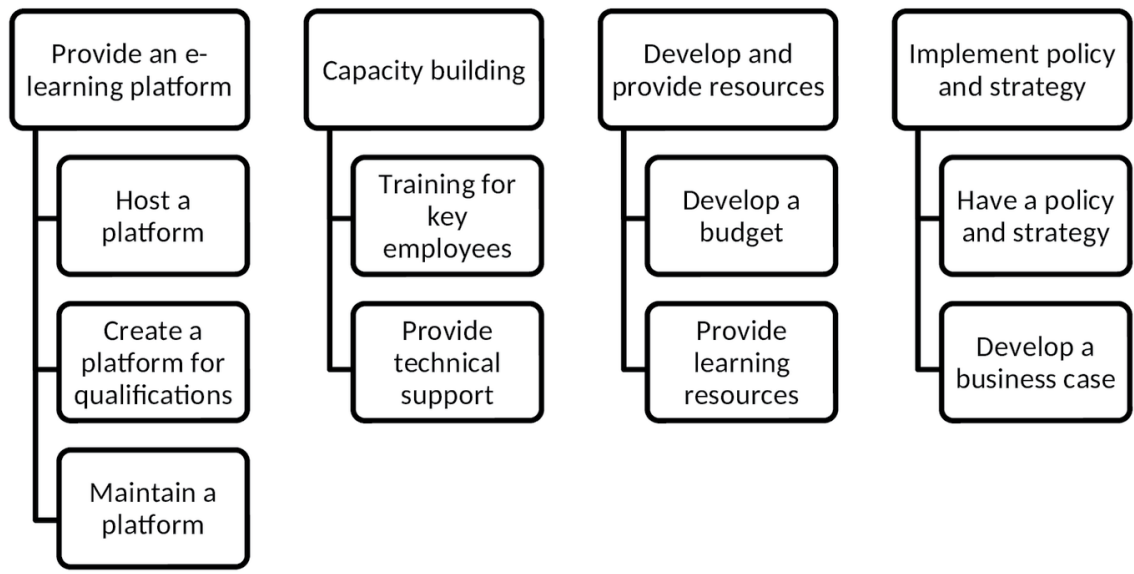

University benchmarks of quality developed for the New Zealand Ministry of Education and Massey University's E-learning policy research.

\section{International Practice in the Support of E-Learning}

A desktop review of strategy, policy documents and approaches to supporting e-learning of a number of international bodies or organisations that regulates and supports e-learning was completed. The purpose of the review was to establish emerging themes that form part of the strategic approach to 
e-learning and that are a part of organisations' strategies in regulating, supporting and evaluating e-learning. A mix of organisations were selected based on the potential applicability of their work to workplace learning although there was no specific organisation identified that has its sole focus on the retail industry. The organisations identified are mandated to ensure quality, assist in improvement of e-learning and support e-learning in a wide range of different contexts from vocational education, higher education, distance education, promotion of technology and ICT in education, and flexible learning. These international organisations or initiatives are:

- The Australian National Vocational Education (VET) and Training e-learning strategy (Department of Industry, Innovation, Science, 2012) which was considered given its vocational, distributed and flexible approach to e-learning;

- The QAA which is the Quality Assurance Agency for Higher Education (QAA) an independent body entrusted with monitoring, and advising on, standards and quality in UK higher education (Steering Group, 2011; Ball \& Manwaring, 2010). The QAA was considered given its overarching role in ensuring quality in e-learning in a wide range of institutions internationally and also within member countries of the UK (QAA, 2010);

- Joint Information Systems Committee (JISC) is an advisory committee to the higher education funding councils of England, Scotland, Wales and Northern Ireland. The mission of JISC is to provide leadership in the innovative use of ICT to support education and research. JISC funds a range of programmes, services and activities that promote and support the use of e-learning (Swedish National Agency For Higher Education, 2008). JISC was considered given its threefold mandate in providing shared services, provision of access to resources and advice and assistance with respect to e-learning;

- Australasian Council on Open, Distance and E-learning (ACODE) is an Australasian organisation for universities that are engaged or interested in open, distance, flexible and e-learning. Its mission is to enhance policy and practice in these areas (Acode, 2014);

- Council for Higher Education Accreditation (CHEA) is a private non-profit national organisation that coordinates accreditation activities in the US. CHEA is the only non-governmental higher education organisation that conducts certification of the quality of regional, faith-based, private career and programmatic accrediting organisations (Uvalić-Trumbić, 2016);

- Ako Aotearoa is New Zealand's National Centre for Tertiary Teaching Excellence and is a consortium of institutions headed by Massey University which includes AUT University, the University of Canterbury, Christchurch College of Education, Universal College of Learning (UCOL), and Manukau Institute of Technology. This organisation was considered given its support focus in e-learning (Ako Aotearoa, 2018);

- Swedish National Agency for Higher Vocational Education (SNA) has a key function to ensure that vocational programmes meet the Swedish labour market's needs for a qualified workforce (Swedish National Agency for Higher Education, 2008);

- The European Centre for the Development of Vocational Training (Cedefop) which is the European Union's reference centre for vocational education and training and provides information on, and analyses of, vocational education and training systems, policies, research and practice (Ehlers, Goertz, Hildebrandt, \& Pawlowski, 2005).

A number of key aspects or themes emerged that are consistent with other findings of this research are indicated in Table 7. They inform and provide inputs into a possible strategy for e-learning in retail.

\section{RECOMMENDATIONS}

Based on the findings of this study, from both the international literature and the South African context, a number of recommendations have been made to assist the wholesale and retail sector in 
Table 7. Policies, support and documentation of international e-learning support organisations

\begin{tabular}{|l|c|c|c|c|c|c|c|c|}
\hline & VET & QAA & ACODE & CHEA & JISC & AKO & SNA & Cedefop \\
\hline $\begin{array}{l}\text { Leverage and development of existing } \\
\text { training and education capacity }\end{array}$ & $\mathrm{x}$ & $\mathrm{x}$ & $\mathrm{x}$ & $\mathrm{x}$ & $\mathrm{x}$ & $\mathrm{x}$ & $\mathrm{x}$ & \\
\hline $\begin{array}{l}\text { Requirement for guidelines and } \\
\text { standards/ codes of good practice/ } \\
\text { benchmarks }\end{array}$ & $\mathrm{x}$ & $\mathrm{x}$ & $\mathrm{x}$ & $\mathrm{x}$ & $\mathrm{x}$ & $\mathrm{x}$ & $\mathrm{x}$ & $\mathrm{x}$ \\
\hline $\begin{array}{l}\text { A differentiated approach for SMEs and } \\
\text { large companies }\end{array}$ & $\mathrm{x}$ & & $\mathrm{x}$ & & & $\mathrm{x}$ & & \\
\hline $\begin{array}{l}\text { Collaboration and cooperation with } \\
\text { other similar organisations to establish } \\
\text { transferrable universally accepted } \\
\text { practices, standards, and skills }\end{array}$ & $\mathrm{x}$ & $\mathrm{x}$ & $\mathrm{x}$ & $\mathrm{x}$ & $\mathrm{x}$ & $\mathrm{x}$ & $\mathrm{x}$ & $\mathrm{x}$ \\
\hline $\begin{array}{l}\text { Blended learning and flexible/distributed } \\
\text { approaches to workplace learning }\end{array}$ & $\mathrm{x}$ & & $\mathrm{x}$ & & & $\mathrm{x}$ & $\mathrm{x}$ & \\
\hline The role of advocacy of e-learning & $\mathrm{x}$ & & $\mathrm{x}$ & $\mathrm{x}$ & $\mathrm{x}$ & $\mathrm{x}$ & & $\mathrm{x}$ \\
\hline
\end{tabular}

the development of an e-learning strategy and with the implementation of e-learning throughout the sector. These recommendations are the following.

\section{Focus of E-Learning Objectives}

- It is recommended that the industry considers the adoption of a systems-based approach to e-learning that views e-learning as technologies, services and stakeholders in its e-learning approach;

- It is recommended that the industry e-learning support should initially focus on learning within a workplace context. The concept of distributed learning as instructional method where e-learning as modality may provide distributed or flexible learning options for employees and allow them to up-skill more rapidly, allows instructor, students, and content to be located in different, noncentralized locations so that instruction and learning can occur independent of time and place, will be the primary area of focus. Other areas where e-learning supports learning such as distance education, e-learning as support to contact based learning and e-learning to support open learning which would be more applicable in an academic learning context, though not excluded, are areas for later consideration and support;

- The support to organisations embarking on e-learning as new modality should focus predominantly on two of the three primary barriers to e-learning identified in workplace e-learning literature - these being content and capability. These barriers are consistent with the needs highlighted by industry. The third barrier to workplace e-learning identified as connectivity may imply a capital investment by relevant stakeholders and/or be impacted by broader policies regarding connectivity. In this context a sector training authority could play a pivotal role in setting technical standards of compliance for systems and technology in line with international practice;

- It is recommended that e-learning is viewed as a modality or method of delivery of post school education and training in line with other modalities such as contact, distance and blended learning. While all learning modalities (distance education, resource-based learning, e-learning, online learning and blended learning) are acknowledged in emerging policies as important vehicles for learning, they should not be equated to learning; 
- E-learning should focus on areas of priority for support that are commonly used internationally within retail sectors such as:

- Types of delivery:

- Blend of classroom and online learning;

- Types of programmes:

- Leadership and management skills;

- Customer handling/service;

- Induction related skills;

- Types of technology:

- Learning management systems;

- Creation of an e-learning quality resource hub - an online collection of research papers, quality tools, training materials, etc., which could be useful to institutions seeking to improve their quality systems, and to quality assurance reviewers. Such a hub should be carefully considered to ensure that it focuses exclusively on the best research and tools.

\section{Mobilise Existing Capacity in Delivery of E-Learning for Workplace Skills Development}

To achieve this objective, organisations should start looking at their goals and training plans and evaluating how e-learning can add value to the attainment of their goals.

\section{Provide Differentiated Support for E-Learning in Larger and Small Retailers}

This includes development of e-learning materials (new and adaption of existing ones) in collaboration with the service providers in order to ensure that the materials are relevant to the needs of the industry; assisting in providing technical support within the organization to employees who may be taking e-learning courses - key employees should be trained to provide these kinds of support, or those who have undergone e-learning can help colleagues; and a facility for e-assessment and moderation and publishing of good practices on e-learning should be provided in the organization.

\section{Provide Training Programmes for Both Large and Small Retailers}

This includes training of key employees on e-learning in order to support e-learning in the workplace, and training of the workforce to upgrade their skills and competences as per the needs of the companies.

\section{Provide Information and Best Practice Support}

Key employees, or those who have undergone e-learning training, should be trained to provide this kind of support to colleagues. A facility for e-assessment and moderation and publishing of good practices on e-learning should also be provided in the organization.

If the above objectives are well implemented, the organizations should be able to achieve the outcomes of increased, efficient and cost-effective ways of training staff and the development of a quality, certified e-learning program. The activities derived from this study, and created as recommendations, are summarised in Figure 4.

\section{CONCLUSION}

A review of retail e-learning studies in the UK, USA and Canada identified training types, barriers, drivers and technologies, confirming that a range of e-learning options have already been implemented internationally in areas that are applicable to a South African wholesale and retail context. An understanding of international wholesale and retail e-learning may lead to faster implementation in a local wholesale and retail context given the level of similarity between formal international and local wholesale and retail. 
Figure 4. Proposed e-learning recommendations

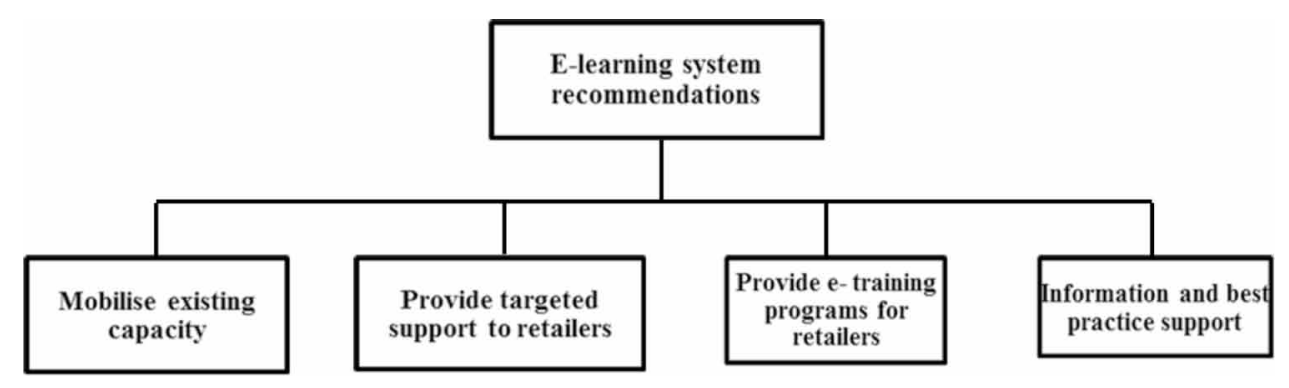

The readiness and enthusiasm of the South African wholesale and retail sector for e-learning is apparent with a range of needs articulated that are within the mandate of the W\&RSETA. Importantly, a number of issues regarding provision of infrastructure, such as the provision of a platform, may not be within the mandate of the W\&RSETA and may require further investigation.

Lastly, in identifying areas where support could be provided to the sector, a review of organisations supporting e-learning internationally provided clarity and international practice in understanding the main streams of support currently rendered to e-learning programmes, such as prioritising the use and expansion of existing e-learning capacity, enhancing collaboration and advocacy of e-learning efforts. 


\section{REFERENCES}

Ako Aotearoa. (2018). Ako Aotearoa website. Retrieved from https://ako.ac.nz/

Anderson, B., Brown, M., Murray, F., Simpson, M., \& Mentis, M. (2006). Global picture, local lessons: E-learning policy and accessibility. Wellington: Massey University. Retrieved from https://www.educationcounts.govt. nz/_data/assets/pdf_file/0005/58289/Global-Picture-Local-Lessons-e-Learning-Policy-and-Accessibility.pdf

Australasian Council on Open, Distance and e-Learning (Acode). (2014). Acode Benchmarks. Retrieved from http://www.acode.edu.au/resources/ACODE_benchmarks.pdf

Australian Flexible Learning Framework. (2011). Practical Guide to e-learning. Canberra Institute of Technology.

Babbie, E., \& Mouton, J. (1998). The Practice of Social Research. Cape Town: Oxford University Press.

Ball, I., \& Manwaring, G. (2010). Making it work: a guidebook exploring work-based learning. Retrieved from http://dera.ioe.ac.uk/1183/1/WBL_Guidelines.pdf

Becker, K., Fleming, J., \& Keijsers, W. (2012). E-learning: Ageing workforce versus technology-savvy generation. Education + Training, 54(5), 385-400. doi:10.1108/00400911211244687

Brown, K. G., \& Charlier, S. D. (2013). An integrative model of e-learning use: Leveraging theory to understand and increase usage. Human Resource Management Review, 23(1), 37-49. doi:10.1016/j.hrmr.2012.06.004

Callahan, J. (2010). The online oxymoron: Teaching HRD through an impersonal medium. Journal of European Industrial Training, 34(8/9), 869-874. doi:10.1108/03090591011081020

Clayton, J., \& Elliott, R. (2008). Using e-learning to build workforce capability: A review of activities. Emerging Technologies Centre, Waikato Institute of Technology. Retrieved from https://www.educationcounts.govt.nz/ publications/e-Learning/58148

Council on Higher Education (CHE). (2012). DHET Draft Policy Framework on Distance Education in South African Universities. Brummeria: CHE. Retrieved from http://www.che.ac.za/media_and_publications/ documents-interest/dhet-draft-policy-framework-distance-education-south

Department of Industry. Innovation, Science, Research and Tertiary Education. (2012). National VET E-learning Strategy 2012-2015. Retrieved from http://www.voced.edu.au/content/ngv\%3A51817

Dixon, G., \& Overton, L. (2015). Retail Sector Benchmark report 2015. Towards Maturity. Retrieved from https://www.towardsmaturity.org/elements/uploads/2015_Sector_Benchmark_Report_-_Retail_FINAL.pdf

Ehlers, U.-D., Goertz, L., Hildebrandt, B., \& Pawlowski, J. M. (2005). Quality in e-learning: Use and dissemination of quality approaches in European e-learning. Thessalonika: European Centre for the Development of Vocational Training (Cedefop). Retrieved from http://www.rcc.gov.pt/SiteCollectionDocuments/Qualitye-learning05.pdf

Ettinger, A., Holton, V., \& Blass, E. (2005). E-learner experiences: Learning from the pioneers. Industrial and Commercial Training, 37(6), 286-290. doi:10.1108/00197850510617550

Fiehl, S., Diaz, M., \& Solom, A. (2011). European e-learning Barometer. CrossKnowledge, Fēfaur and IPSOS. Retrieved from https://www.crossknowledge.com/en-gb/media-center/news/elearning-barometer-europe

Flick, U. (1998). An Introduction to Qualitative Research. London: Sage.

Henning, E., van Rensburg, W., \& Smit, B. (2004). Finding your way in qualitative research. Pretoria: Van Schaik.

SETA Insurance. (2014). GUIDELINE: E-Learning. Retrieved from http://www.inseta.org.za/downloads/E_ learning_Guideline_2012.pdf

Lee, T. W. (1999). Using Qualitative Methods in Organizational Research. Thousand Oaks: Sage.

Maree, K. (2010). First steps in research. Pretoria: Van Schaik.

Massmart. (2013). Massmart University. Retrieved from http://www.massmart.co.za/careers/massmart-corporate-university/

MrPrice. (2015). MrPrice Integrated Annual report. Retrieved from http://www.mrpricegroup.com/mr-pricegroup-investor-relations.aspx?loc $=\mathrm{rr}$ 
Pappas, C. (2015). The Top 5 Online training benefits in the retail sector. E-Learning Industry. Retrieved from http://elearningindustry.com/top-5-online-training-benefits-in-the-retail-sector

Pick 'n Pay. (2014). Integrated annual report 2014. Retrieved from https://www.picknpay-ir.co.za/downloads/ annual-report/2014/pick-n-pay-integrated-annual-report-2014.pdf

QAA. (2010). Code of practice for the assurance of academic quality and standards in higher education. Collaborative provision and flexible and distributed learning (including e-learning) - Amplified version October 2010. The Quality Assurance Agency for Higher Education. Retrieved from http://www.bbk.ac.uk/linkinglondon/ resources/apel-credit-resources/pub_Nov2010_QAA_COP_section_2_HE_guidance.pdf

Rabak, L., \& Cleveland-Innes, M. (2006). Acceptance and Resistance to Corporate E-Learning : A Case from the Retail Sector. Journal of Distance Education, 21(2), 115-134.

Retail Council of Canada. (2015). Retail Training and Employee Development Benchmark Survey 2015. Retrieved from https://webcache.googleusercontent.com/search?q=cache:hWbbkJRIS1cJ:https://www.retailcouncil.org/ sites/default/files/documents/Retail_Training_Survey3.pdf $+\& c d=1 \&$ hl=en\&ct=clnk\&gl=za\&client=firefox-b

Shoprite. (2015). Shoprite Holdings Integrated Report. Retrieved from https://www.shopriteholdings.co.za/ content/dam/MediaPortal/documents/shoprite-holdings/integrated-report/2015/5527_SR_IR2015_E.pdf

Spar. (2014). Spar Integrated Annual Report 2014. Retrieved from https://www.spar.co.za/getattachment/ fc16b138-ed55-4d20-9305-ef34e24c7af8/00000000-0000-0000-0000-000000000000-(11).aspx

Steering Group. (2011). A Toolkit for Harnessing Quality Assurance Processes for Technology Enhanced Learning. Quality Assurance-Quality Enhancement in e-Learning Special Interest Group. Retrieved from http:// qaqe-sig.net/wp-content/uploads/2011/03/Toolkit_version_2011_9_3.pdf

Swedish National Agency for Higher Education. (2008). E-learning quality: Aspects and criteria for evaluation of e-learning in higher education. Retrieved from http://www.eadtu.nl/e-xcellencelabel/files/0811R.pdf

Training Room online. (2014). eLearning Survey of Large and Medium Companies in the Wholesale \& Retail Sector. August. Cape Town: Training room Online.

Trainingmag. (2014). 2014 Training: Industry Report. Trainingmag Publications, (November/December), 16-29. Retrieved from http://www.trainingmag.com/sites/default/files//magazines/2014_11/2014-Industry-Report.pdf

Uvalić-Trumbić, S. (Ed.). (2016). The CIQG International Quality Principles : Toward a Shared Understanding of Quality. Washington, DC: Council for Higher Education Accreditation. Retrieved from https://www.chea. org/userfiles/CIQG/Principles_Papers_Complete_web.pdf

W\&RSETA. (2014). Wholesale \& Retail Sector Education and Training Authority (W\&RSETA) Sector Skills Plan 2011-2016, 2014 Update.

W\&RSETA. (2016). Wholesale and Retail SETA website. Retrieved from http://www.wrseta.org.za/

Jonathan Aspeling holds M.Com (Business Management) and B.Proc (Law) degrees and a Post Graduate Diploma in Education. He is currently a lecturer in the Department of Retail Business Management at the Cape Peninsula University of Technology (CPUT). Previously he was the Manager of, and established, the Retail Leadership Academy at CPUT. He has extensive experience in the development of e Learning systems on different learner management systems. He also has project management skills and management experience in different disciplines including financial services, e-retailing and small business development. He has published a number of papers in academic journals and is currently working on his doctorate in retail management.

Roger Mason is the Wholesale and Retail Leadership Chair at Cape Peninsula University of Technology, and is also a Retired Research Professor in Marketing at Durban University of Technology. He has lectured in retail, marketing, management, and strategy. He has presented international conference papers and published sixty journal papers, both locally and internationally. His business background includes marketing management and consultancy in a variety of industries. He holds $P h D, M B L$, and BA degrees and diplomas in marketing, market research, and education. 